\title{
Benthic community response to iceberg scouring at an intensely disturbed shallow water site at Adelaide Island, Antarctica
}

\author{
Dan A. Smale*, David K. A. Barnes, Keiron P. P. Fraser, Lloyd S. Peck \\ British Antarctic Survey, Natural Environment Research Council, High Cross, Madingley Road, Cambridge CB3 OET, UK
}

\begin{abstract}
Disturbance is a key structuring force influencing shallow water communities at all latitudes. Polar nearshore communities are intensely disturbed by ice, yet little is known about benthic recovery following iceberg groundings. Understanding patterns of recovery following ice scour may be particularly important in the West Antarctic Peninsula region, one of the most rapidly changing marine systems on Earth. Here we present the first observations from within the Antarctic Circle of community recovery following iceberg scouring. Three grounded icebergs were marked at a highly disturbed site at Adelaide Island $\left(\sim 67^{\circ} \mathrm{S}\right)$ and the resultant scours were sampled at $<1,3,6,12,18$ and 30 to 32 mo following formation. Each iceberg impact was catastrophic in that it resulted in a 92 to $96 \%$ decrease in abundance compared with reference zones, but all postscoured communities increased in similarity towards 'undisturbed' assemblages over time. Taxa recovered at differing rates, probably due to varying mechanisms of return to scoured areas. By the end of the study, we found no differences in abundance between scoured and reference samples for 6 out of 9 major taxonomic groups. Five pioneer species had consistently elevated abundances in scours compared with reference zones. Variability between the reference zones was high and scour assemblages became comparable to those at reference zones after just 12 mo of recovery. The study site is intensely disturbed by icebergs and the relatively simple infaunal community is well adapted to recover rapidly from disturbance events. Water movements induced by wave action and iceberg groundings at the site are likely to advect small fauna into newly formed scours and promote recovery.
\end{abstract}

KEY WORDS: Ice scour $\cdot$ Disturbance $\cdot$ Antarctica $\cdot$ Benthos

Resale or republication not permitted without written consent of the publisher

\section{INTRODUCTION}

The immediate response of a community to a disturbance event and its capacity to recover are of major interest to ecologists - particularly now, at a time of increasing types, frequencies and intensities of anthropogenic impacts (Jackson et al. 2001). Disturbance events across spatial and intensity scales play many roles in communities and ecosystems, not least maintaining diversity (Connell 1978). Significant changes in benthic community structure have been described following a wide range of both natural and anthropogenic disturbance events. For example, the effects of anthro- pogenic activities such as fishing practices (Kaiser \& Spencer 1996, Thrush \& Dayton 2002) and oil spills (Smith \& Simpson 1998, Jewett et al. 1999) have been extensively covered, as have natural disturbances, including intense storms (Pearson 1981, Dollar \& Tribble 1993), volcanic eruptions (Lovell \& Trego 2003) and feeding events (e.g. by gray whales, Oliver \& Slattery 1985). However, the timescales and processes involved in benthic recovery from one of the most widespread and intense forms of disturbance on the planet, ice scour, are poorly understood. Ice scouring, the process of ice impacting the seabed, is a fundamental ecological process in Antarctica and has been described as 
one of the 5 most significant disturbances acting at the ecosystem level (Gutt \& Starmans 2001). In Antarctica alone, there are $\sim 5500 \mathrm{~km}$ of ice-shelf-free shallow coastline, most of which could be impacted by one of the 300000 icebergs (Orheim 1987) that float around the Southern Ocean.

Iceberg impacts result in high mortality to benthic assemblages (Lenihan \& Oliver 1995, Conlan et al. 1998, Peck et al. 1999, Smale et al. 2007) and many shallow water polar communities are held at early successional stages by chronic ice scour (Dayton et al. 1974, McCook \& Chapman 1993, Barnes 1995, Pugh \& Davenport 1997). Paradoxically, some major taxa inhabiting the highly disturbed nearshore environment around Antarctica are as rich, and in some cases richer, than those in temperate regions (Barnes \& Brockington 2003). It has been suggested that ice disturbance has promoted biodiversity over ecological timescales by removing dominant competitors, increasing habitat heterogeneity and sustaining a diverse group of scavengers (Arntz et al. 1994, Barnes 2002, Gutt \& Piepenburg 2003). However, the time required for shallow water Antarctic assemblages to recover from ice scouring is currently unknown. Understanding such fundamental processes is of particular importance in the West Antarctic Peninsula region, perhaps the fastest-changing marine ecosystem on Earth. Air temperatures have risen by $3^{\circ} \mathrm{C}$ in the last $50 \mathrm{yr}$ (Turner et al. 2005) and the summer surface temperature of the Bellingshausen Sea has warmed by $\sim 1^{\circ} \mathrm{C}$ since the 1950s (Meredith \& King 2005). Environmental changes associated with this rapid warming include increased iceberg loading into coastal waters (due to accelerating glaciers and retreating ice shelves) and a decreased extent and duration of winter sea ice (de la Mare 1997, Smith \& Stammerjohn 2001, Vaughan et al. 2003, Pritchard \& Vaughan 2007).

Only one iceberg scour within the Southern Ocean (at $60.5^{\circ} \mathrm{S}$ ) has been sampled to monitor community recovery. Following an initial $>99.5 \%$ reduction in infaunal abundance, Peck et al. (1999) found no measurable recovery in some components (large bivalves) of the disturbed community during their $250 \mathrm{~d}$ study period. Conversely, meiofauna had recovered to control levels within $30 \mathrm{~d}$ (Lee et al. 2001). In the Canadian Arctic, a comprehensive study by Conlan \& Kvitek (2005) involving 19 iceberg scours at various stages of recolonisation suggested that $>10 \mathrm{yr}$ is required for scoured communities to recover to background levels. No such data are available for shallow water scours within the Antarctic Circle. In this study, patterns of post-disturbance recovery in 3 nearshore soft sediment iceberg scours were monitored for 30 to 32 mo at Adelaide Island, West Antarctic Peninsula.

\section{MATERIALS AND METHODS}

Study site. The study was conducted at Hangar Cove, adjacent to the British Antarctic Survey research station at Rothera Point, Antarctica (67 $34^{\prime} 07^{\prime \prime} \mathrm{S}$, $68^{\circ} 07^{\prime} 30^{\prime \prime} \mathrm{W}$ ) (Fig. 1). The substratum at this site consists of glacial cobbles with an overlying layer of silt (of variable thickness). The substratum gradient is shallow and consistent from 0 to $50 \mathrm{~m}$ depth. Hangar Cove is exposed to the prevailing northerly winds and is subjected to intense iceberg scouring during the fast icefree austral summer. At $\sim 15 \mathrm{~m}$ depth in the middle of the cove, typically any one point is scoured on an annual basis, but some areas may be impacted up to 3 times a year (Brown et al. 2004, Smale et al. 2007). Stable fast ice forms at this site during winter and persists for 3 to 8 mo (British Antarctic Survey, unpubl. data). Reports of anchor ice formation at this site are very rare. With respect to anthropogenic disturbance to benthos at this site, a runway to the east of the study area was constructed in 1991 but caused only very localised disturbance, whilst contamination from the research station is thought to be minimal (Hughes 2004). As such, infaunal communities at Hangar Cove are largely unaffected by human activities.

Three distinct iceberg groundings were observed in Hangar Cove between March and July 2004. Each iceberg travelled from the north with the prevailing wind and remained grounded for $\sim 48 \mathrm{~h}$. The position of each grounded iceberg was fixed with GPS and SCUBA divers marked the new scour once the iceberg had retreated (Fig. 1). The selected study scours were formed at $\sim 14 \mathrm{~m}$ depth. Coloured pegs were randomly placed in the newly formed trough zones; these marks were subsequently used as sample points. Scour berms were not sampled because they were small and poorly formed. Scours varied in length from 2.8 to $5.8 \mathrm{~m}$ and in mean width from $1.1 \pm 0.1 \mathrm{~m}$ to $1.8 \pm 0.0 \mathrm{~m}$ (Table 1 ). Scours were elongated, with a mean width:length ratio of $2.7 \pm 0.6$ (all means are $\pm \mathrm{SE}$ ). The scours were sampled at regular intervals for 30 mo (April 2004 to December 2006).

Sampling protocol. The soft sediment layer at Hangar Cove varied irregularly in thickness from $\sim 2 \mathrm{~cm}$ to more than $20 \mathrm{~cm}$. Due to this heterogeneity, sediment sampling by traditional coring methods proved to be impractical. An aluminium scoop and mesh sampler was developed to sample $0.03 \mathrm{~m}^{2}$ of the sediment to a depth of $2 \mathrm{~cm}$. At each sampling event, SCUBA divers collected 3 replicate samples from the impacted trough region of each scour. The first samples were collected from each scour within $20 \mathrm{~d}$ of scour formation (hereby referred to as $t<1 \mathrm{mo}$ ) and subsequent samples were taken at 3, 6, 12, 18 and 30 mo after scour formation. Two zones at the study site 

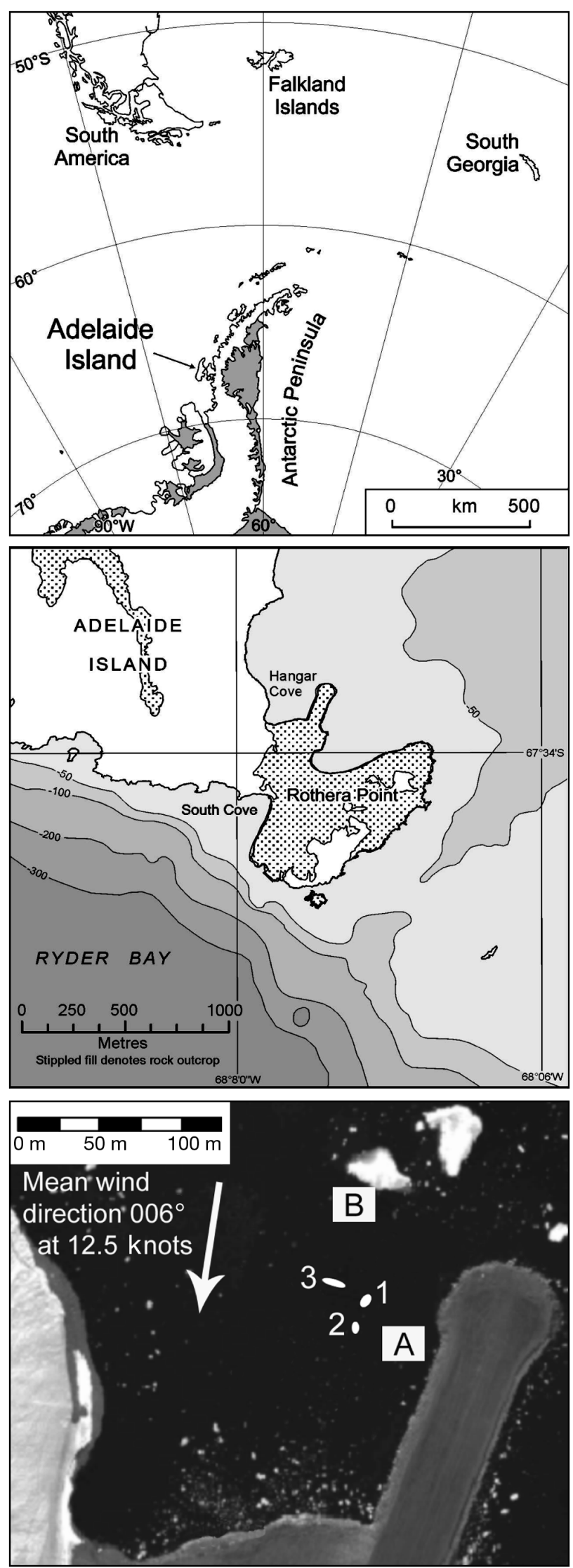

Table 1. Length (L), width (W), depth (D) and date of the iceberg impact for each of the 3 study scours at Hangar Cove, Adelaide Island, Antarctica. Width is a mean of 3 random measurements $\pm \mathrm{SE}$

\begin{tabular}{|lcccc|}
\hline Scour & L $(\mathrm{m})$ & $\mathrm{W}(\mathrm{m})$ & $\mathrm{D}(\mathrm{m})$ & Impact date \\
\hline 1 & 3.1 & $1.8 \pm 0.0$ & 14 & 23 Mar 2004 \\
2 & 2.8 & $1.1 \pm 0.1$ & 13 & 15 Jun 2004 \\
3 & 5.8 & $1.1 \pm 0.3$ & 15 & 01 Jul 2004 \\
\hline
\end{tabular}

were identified in order to obtain unscoured reference samples (Fig. 1). 'Reference A' was at located $\sim 10 \mathrm{~m}$ away from Scour 2 and at a similar depth $(\sim 13 \mathrm{~m})$ to the scours. This reference zone is partially protected from incoming icebergs by the Rothera airstrip and SCUBA divers detected no evidence of recent scouring. 'Reference $\mathrm{B}^{\prime}$ was at $25 \mathrm{~m}$ depth and was infrequently disturbed in comparison to the shallower scoured areas. Smale et al. (2007) quantified iceberg impact frequencies at Hangar Cove for $2 \mathrm{yr}$ and did not detect disturbance at this zone during the study period. Unfortunately, due to the difficulties of accessing the site during the winter months, the reference zones were not sampled as frequently as the scours, leading to an unbalanced sampling design. Reference zones were sampled randomly on 3 occasions during the study period, with 6 replicate samples taken on each occasion.

Faunal analysis. Sediment samples were sieved through $0.5 \mathrm{~mm}$ mesh and preserved in $70 \%$ ethanol. Samples were sorted to the lowest possible taxonomic level (typically species) immediately after collection. Organisms were blotted dry for $1 \mathrm{~min}$ and then weighed to obtain wet mass measurements such that we could estimate faunal biomass.

Statistical analysis. Mean values of total faunal abundance, species richness and total biomass were calculated from the 3 replicate samples from each of the 3 scours on each sampling occasion. Means of these parameters were also calculated from the 2 reference sites to compare scoured and undisturbed communities over time. The mean abundances of higher taxonomic groups from both scours and reference zones were also plotted against time. All means are presented \pm SE. Error bars represent SE in all figures,

Fig. 1. Top panel: Adelaide Island on the Antarctic Peninsula. Middle panel: Rothera Point, with Hangar Cove to the north of Rothera Research Station; dotted area = rock outcrop. Bottom panel: Hangar Cove, with the approximate positions, sizes and orientations of the study scours labeled $1-3$, and the locations of reference zones $(\mathrm{A}, \mathrm{B})$ indicated by white boxes. Mean wind direction and speed also shown 
although in some cases only the positive bar is shown (for clarity). The differences in the abundances of major taxa between scour and reference samples on both the initial sampling occasion and the final occasion were assessed with 1-way ANOVA (using Minitab 14.0 software).

Multivariate analyses were applied using PRIMER v. 6, as described by Clarke \& Warwick (2001), to determine underlying patterns to assemblage structure. Before generating Bray-Curtis coefficient matrices, abundance data required square-root transformations to down-weight the influence of 2 highly abundant species and to give greater importance to moderately abundant species. The similarities between scoured communities and those at each of the reference zones at each sampling date were determined using 1-way ANOSIM (Clarke 1993). Replicate samples $(n=6)$ from the reference zones were averaged for each sampling event before comparisons were made. To illustrate increasing similarity between scour samples and reference samples during recovery, 1-ANOSIM R values (rather than simply ANOSIM R) were plotted against time (no negative $\mathrm{R}$ values were obtained), as done previously by Conlan \& Kvitek (2005). This approach examines the similarities between disturbed and reference communities over time, and if a significant 1 -ANOSIM R value of $\sim 0.8$ to 1.0 is reached, it can be inferred that assemblages are no longer statistically dissimilar. Furthermore, a 2-way crossed ANOSIM test was applied to detect differences between scour groups over time (3 scour groups vs. 5 time groups) and reference groups over time ( 2 reference groups vs. 3 time groups).

Non-metric multidimensional scaling (MDS) was applied to assess the grouping structure of scour samples collected on each sampling occasion compared with reference samples, which were averaged for each sampling occasion. The multivariate dispersion of replicates within each sample set was determined using multivariate dispersion (MVDISP). Taxa that contributed most to the observed differences were determined using the similarity percentage (SIMPER) procedure, which calculates the contribution of each taxon to the overall dissimilarity between 2 groups of samples (in this case, scoured vs. reference).

\section{RESULTS}

\section{Univariate measures of community recovery}

A total of $\sim 33000$ individuals representing 66 taxa were sampled (for a full list of taxa inhabiting Hangar Cove see Smale 2007). Most taxa were identified to species level, with the exceptions of one anthozoan,
5 ostracod specimens and nematodes. Overall, small infaunal bivalve molluscs, polychaetes and nematodes, which formed $54 \%, 26 \%$ and $11 \%$ of all the individuals sampled, respectively, dominated the benthic community. Following each scouring event, faunal abundance and species richness were markedly lower in scours compared with reference zones. In comparison to a mean value for all the reference samples, macrofaunal abundance was $~ 96 \%$ lower in Scours 1 and 2 and $\sim 92 \%$ lower in Scour 3. The number of species per sample following ice scouring were $\sim 58 \%, \sim 64 \%$ and $\sim 65 \%$ lower than in reference samples in Scours 1, 2 and 3 , respectively. However, variation in total sample biomass following scouring was not consistent between scours. When compared with the mean biomass of reference samples, Scour 1 had a $280 \%$ higher biomass value on the first sampling occasion $(t<1 \mathrm{mo})$. This was due to the presence of a number of the large regular echinoids Sterechinus neumayeri, which had formed aggregations in the recently formed scour after the iceberg had retreated. As high densities of large echinoids were not present in the undisturbed reference samples, post-scour biomass was considerably higher in this scour. Conversely, large echinoids were not sampled in Scours 2 or 3, resulting in biomass values $\sim 98 \%$ and $96 \%$ lower than in reference zones, respectively.

Over the 30 to 32 mo sampling period, all 3 scours showed some recovery, in terms of abundance, towards the reference zones. Thirty-two mo after the initial disturbance, faunal abundance in Scour 1 had recovered to $\sim 30 \%$ of reference abundances (scour abundance reached $190 \pm 16$ ind. $0.03 \mathrm{~m}^{-2}$ compared with a mean value of $637 \pm 43$ ind. $0.03 \mathrm{~m}^{-2}$ from the reference zones). After $30 \mathrm{mo}$, Scour 2 had recovered to $\sim 44 \%$ of the reference abundance whilst Scour 3 was comparable to the reference zones at $~ 95 \%$ recovery (Fig. 2A) Species richness recovered to levels comparable to the reference zones in considerably less time (Fig. 2B). The mean number of species present per sample (averaged across all sampling occasions) for Reference A was $20.4 \pm 0.7$, whilst there were 18.1 \pm 0.8 species present per sample at Reference B. Richness in Scours 2 and 3 were comparable after just 6 mo $(17.7 \pm 1.7$ and $17.3 \pm 0.9$ species per sample, respectively), whilst Scour 1 reached similar levels after 12 mo of recovery $(20.3 \pm 1.5$ species per sample). Biomass values were highly variable between replicates, times and scours. Mass measurements were skewed by small numbers of the large echinoid Sterechinus neumayeri and the ophiuroid Ophionotus victoriae, which were present in some scours on some occasions. These taxa were rarely sampled at the reference zones, and as a result, the biomass values were much less variable between both replicates and times (Fig. 2C). Fig. 2C 


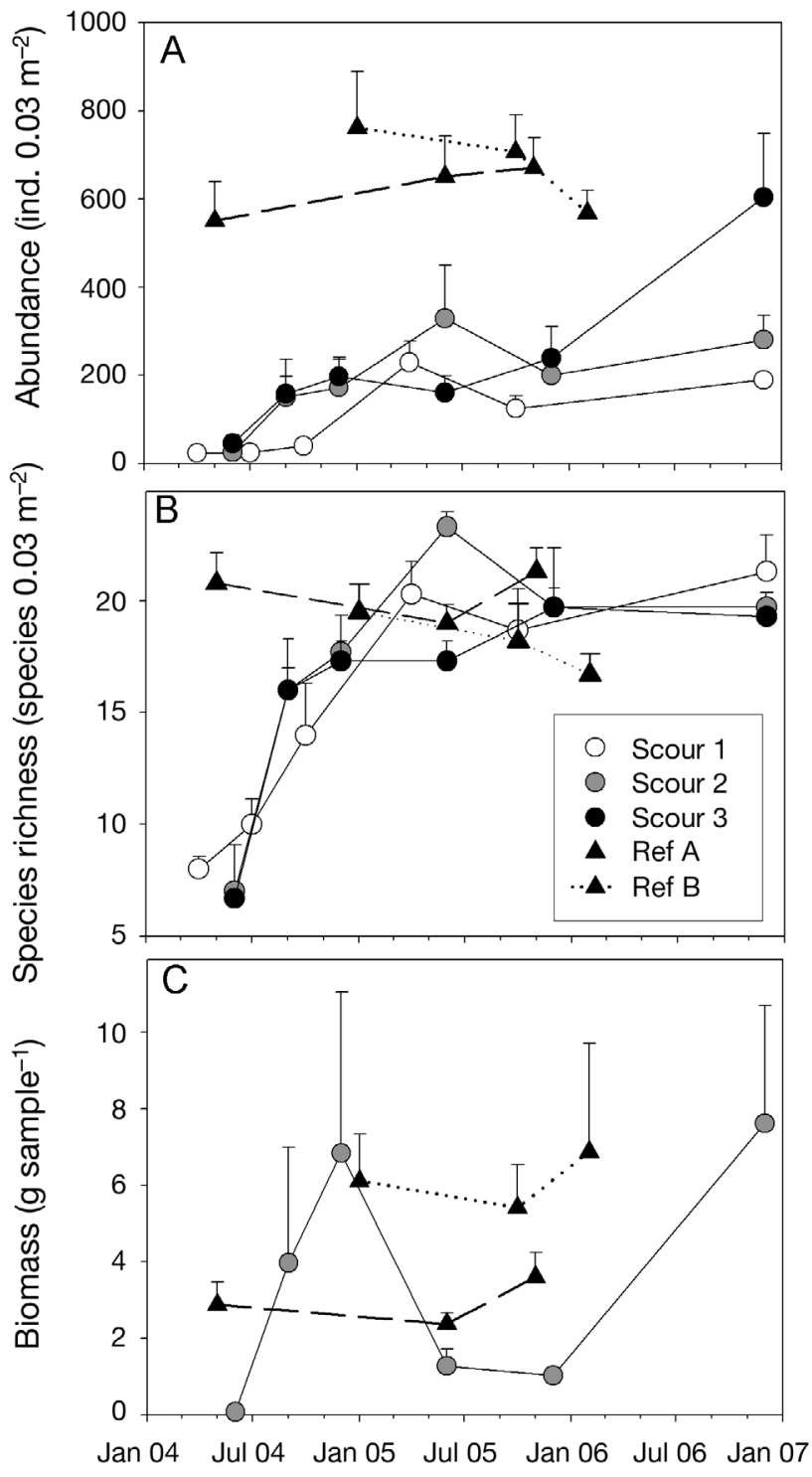

Fig. 2. (A) Total faunal abundance, (B) species richness and (C) total biomass of scour samples through recovery at Adelaide Island, Antarctica (means of 3 samples $\pm \mathrm{SE}$ ). Scours were formed less than 1 mo before the first sample occasion. Biomass data were highly variable; Scour 2 data shown only. Data from both reference sites are also shown (means of 6 samples $\pm \mathrm{SE}$ )

shows only the changes in biomass over time for Scour 2 (to retain clarity on the plot), but demonstrates clearly the high variability and lack of a strong trend. Results for Scours 1 and 3 were similarly highly variable and showed no clear trend.

\section{Response of major taxonomic groups}

Abundance data was separated into major taxonomic groups in order to identify taxon-specific trends in recovery following ice scour. The results of 1-way ANOVA tests suggested that each taxonomic group could be categorised in 4 ways: (1) taxa that had significantly lower abundances in scours on the first sampling occasion time but were no longer different after 30 to 32 mo (complete recovery); (2) taxa that had recovered towards the reference zone abundance levels but were still significantly different after 30 to 32 mo (incomplete recovery); (3) taxa that demonstrated no clear trend; and (4) taxa that had consistently higher abundances in scours compared with undisturbed zones (Fig. 3). Taxa showing characteristics of the first group (complete recovery) included the ostracods, polychaetes and uncommon worms (priapulans and nemerteans). On the first sampling occasion, scour abundances were significantly lower than reference abundances; however, by the end of the study there were no significant differences in the abundance of these taxa between scour and reference samples (Fig. 3A-C). The bivalve molluscs and nematodes demonstrated some recovery towards undisturbed abundances during the study, but were still significantly less abundant in scours after 30 to 32 mo (Fig. 3D,E). However, it should be noted that whilst a high number of nematodes were retained on the $0.5 \mathrm{~mm}$ mesh, the majority of nematodes would have passed through this mesh size. Thus, the abundance values of nematodes presented here are likely to be biased towards large individuals and may not be an accurate representation of this taxa as a whole. Highly mobile crustaceans and gastropod molluscs showed no clear trend, as scour and reference abundances were not significantly different at the beginning or at the end of the study (Fig. 3F-H). Echinoderm abundances were highly variable in scour samples, but echinoderms were generally more abundant in scours compared with reference zones (Fig. 3I).

\section{Multivariate measures of community recovery}

In all 3 scours, communities showed a general trend of increasing similarity towards reference communities over time. MDS ordinations of scour samples and samples from the sheltered reference zone demonstrated this pattern (Fig. 4). The MDS plots for each scour suggested that the samples collected on the first sampling occasion, within 1 mo of scour formation, were well separated from all the other scour and reference samples. However, scour samples collected after 6 mo of recovery were grouped considerably closer to the reference zone assemblages (Fig. 4). The MDS plot of all scours suggested some partitioning between both scours and reference zones. The significance of these groupings was examined with 2-way crossed ANOSIM 

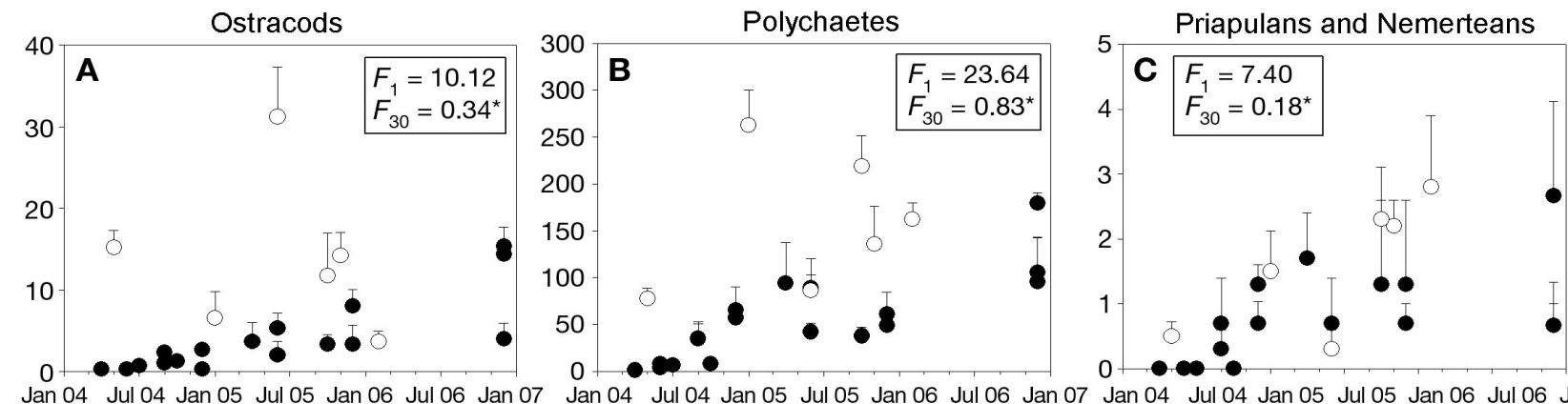

7 Jan 04 Jul 04 Jan 05 Jul 05 Jan 06 Jul 06 Jan 07
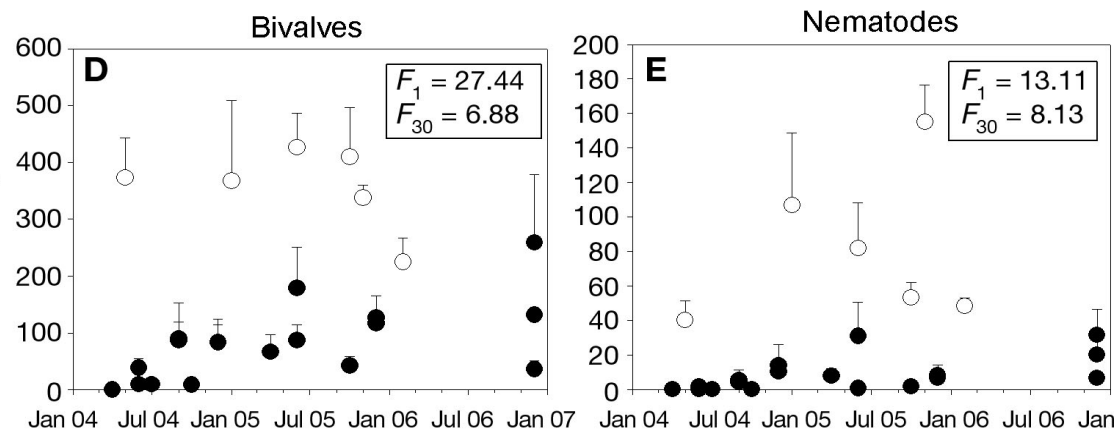

Amphipods
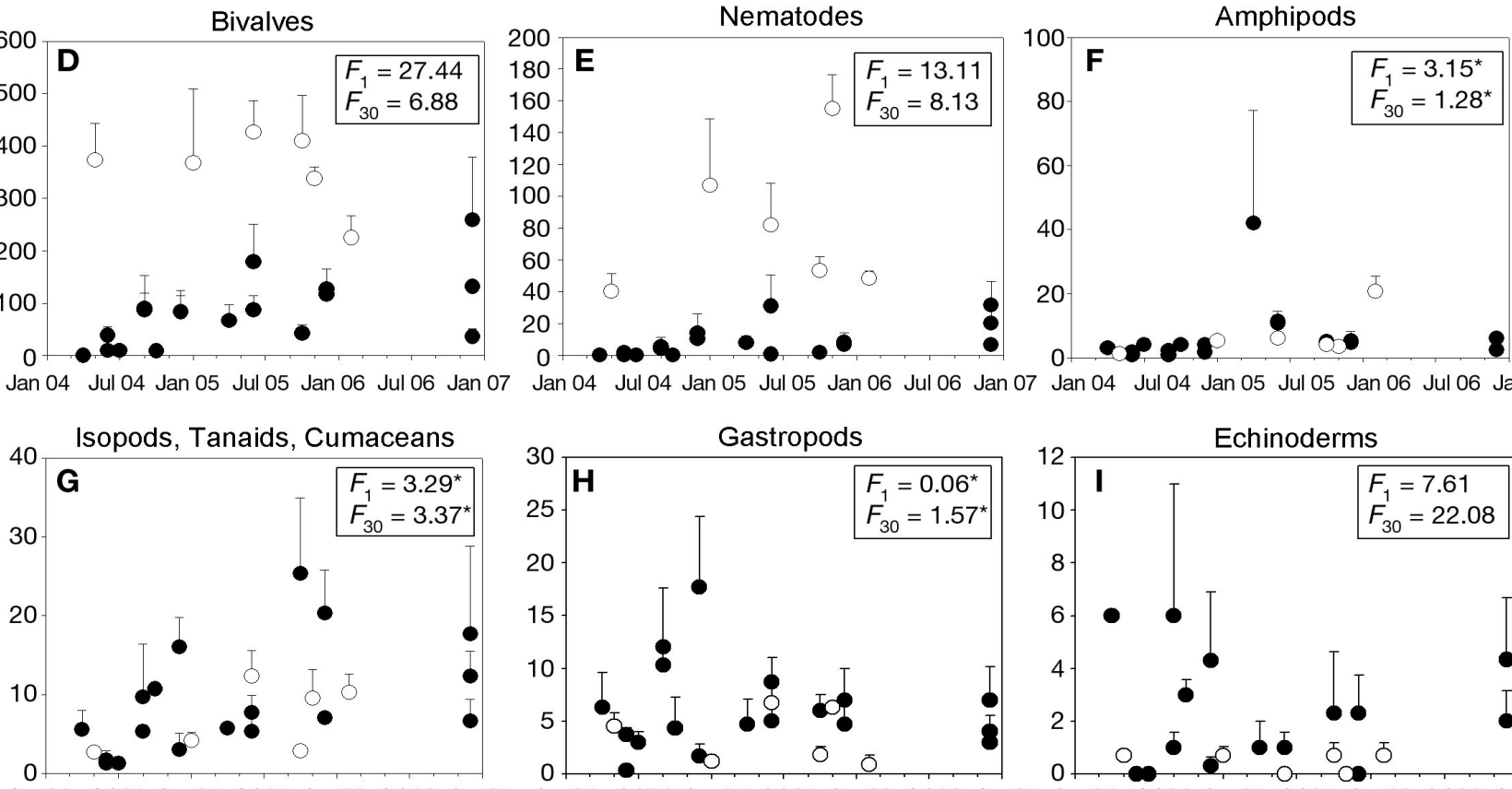

Jan 04 Jul 04 Jan 05 Jul 05 Jan 06 Jul 06 Jan 07
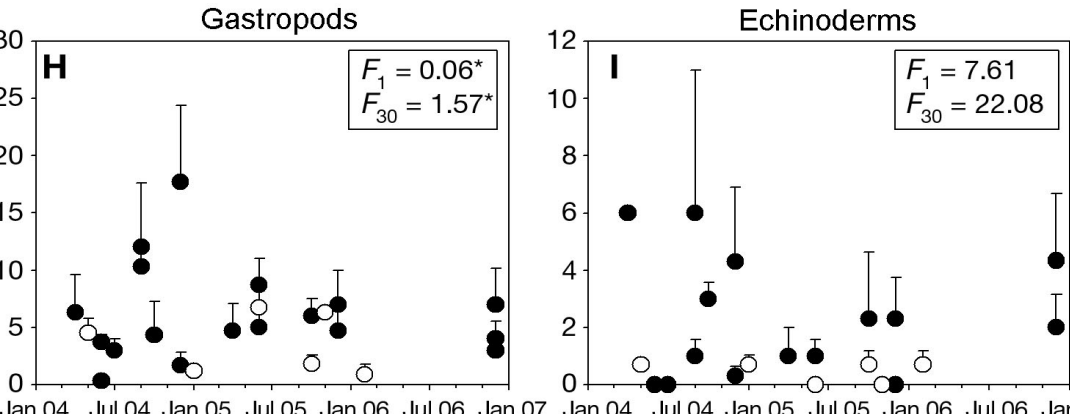

Sampling date

Fig. 3. Post-disturbance changes in abundances of major taxa found in scours ( ) compared with undisturbed reference abundances $(O)$. Data are means \pm SE (scours: $n=3$, refs: $n=6$ ). Scours were formed less than 1 mo before the first sample occasion. Differences in the abundance of taxa between all scour samples and all reference samples were tested with 1-way ANOVA (total $\mathrm{df}=44$ ) at $1 \mathrm{mo}$ after disturbance $\left(F_{1}\right)$ and 30 to $32 \mathrm{mo}$ after disturbance $\left(F_{30}\right)$. An asterisk $\left({ }^{*}\right)$ denotes $F$ values that were non-significant $(p>0.05)$. Taxa showed: complete recovery $(A-C)$, incomplete recovery $(D, E)$, no trend $(F-H)$ or elevated abundances in scours (I)

tests (groups averaged across time), which suggested that scours were moderately distinct, but this spatial variation was comparable to that observed between the 2 reference zones (Table 2). Furthermore, a low but significant $R$ value $(0.28)$ showed that the reference assemblages were not entirely similar throughout the 3 sampling occasions (i.e. we observed slight but significant background temporal variation).

A series of 1-way ANOSIM tests between each recovery time group and each reference zone demonstrated a general trend in increasing similarity towards the reference community during the study period (Fig. 5). On the whole, recovering assemblages were more similar to Reference B (at $25 \mathrm{~m}$ depth in the mid- dle of the bay) than Reference A (at a similar depth but more protected from ice scouring). Scour assemblages were highly dissimilar from those at the reference zones until 12 mo of recovery time, when 1-ANOSIM values ranged from 0.07 to 0.32 compared with Reference $A$, and from 0.31 to 0.71 compared with Reference B (Fig. 5). Thus, with such high background spatial variability (between reference zones) these ANOSIM values indicated that assemblages in some of the scours were not particularly dissimilar from undisturbed assemblages after just 12 mo of recovery. Furthermore, the variation within sample sets from each scour decreased over time (Table 3). Samples collected immediately after the disturbance events were highly 

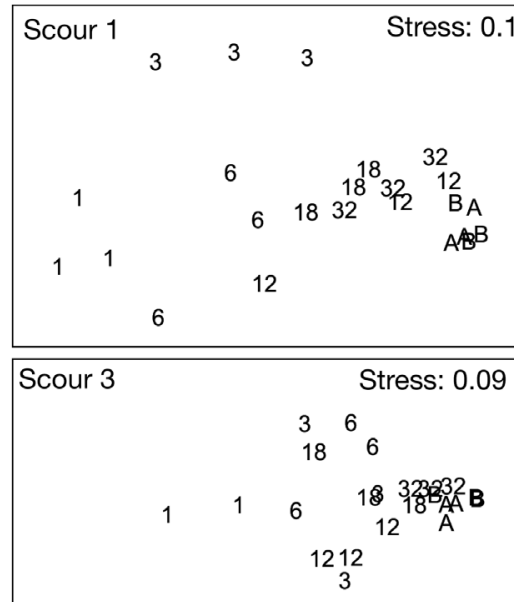

Fig. 4. Post-disturbance samples from each scour compared with reference samples (A and B), collected from Adelaide Island, Antarctica. Scour samples were taken at $<1,3,6,12,18$ and 30-32 mo following iceberg disturbance, as indicated by the sample labels. Final MDS plot shows averages of scour samples from all scours. Abundances were square root transformed before constructing a Bray-Curtis similarity matrix variable, whilst following 30 to $32 \mathrm{mo}$ of recovery, the spatial variability within scours was comparable to that observed at reference zones (Table 3 ).

Generally, species were either more abundant in the reference samples or uncommon in both scoured and undisturbed sediments. However, 5 species had notably greater mean abundances in scour samples compared to reference samples including the regular echinoid Sterechinus neumayeri, which was 5 times more abundant in scours than references zones (Table 4). The species that contributed most to the dissimilarity between scoured and samples from Reference A were determined using the SIMPER procedure. Again, the dissimilarities at species level between scour and reference samples were greatly reduced on the final sampling occasion, compared with the first. The bivalve mollusc Mysella charcoti and
Table 2. Results of 2-way crossed ANOSIM R comparisons of scour, reference (Ref) and time groups (999 permutations) Scour time groups are 1, 3, 6, 12, 18 and 30 mo following disturbance, reference time groups are 1 to 3 random sampling occasions conducted during the study

\begin{tabular}{|lcc|}
\hline Group & $\mathrm{R}$ & $\mathrm{P}$ \\
\hline Scours across time & 0.46 & 0.001 \\
Pairwise: & & \\
Scour 1 vs. Scour 2 & 0.59 & 0.001 \\
Scour 1 vs. Scour 3 & 0.56 & 0.001 \\
Scour 2 vs. Scour 3 & 0.32 & 0.013 \\
Ref A vs. Ref B & 0.56 & 0.001 \\
Time across refs & 0.28 & 0.001 \\
\hline
\end{tabular}

Table 3. Multivariate dispersion (MVDISP) values for each set of scour samples taken from each scour and at each sampling time (mo following disturbance). A higher value indicates greater dispersion within the group of replicate samples. As the index is a relative measure, the values for the reference (Ref) sites differ slightly when compared with each scour sample set

\begin{tabular}{|lccc|}
\hline \multirow{2}{*}{ Time } & \multicolumn{3}{c|}{ Scour } \\
\cline { 2 - 4 } & 1 & 2 & 3 \\
\hline 1 & 1.2 & 1.7 & 1.7 \\
3 & 1.7 & 1.4 & 1.5 \\
6 & 1.4 & 1.4 & 1.3 \\
12 & 1.4 & 0.9 & 1.1 \\
18 & 1.0 & 0.9 & 1.1 \\
$30-32$ & 0.7 & 0.7 & 0.4 \\
Ref A & 0.3 & 0.5 & 0.4 \\
Ref B & 0.2 & 0.3 & 0.3 \\
\hline
\end{tabular}

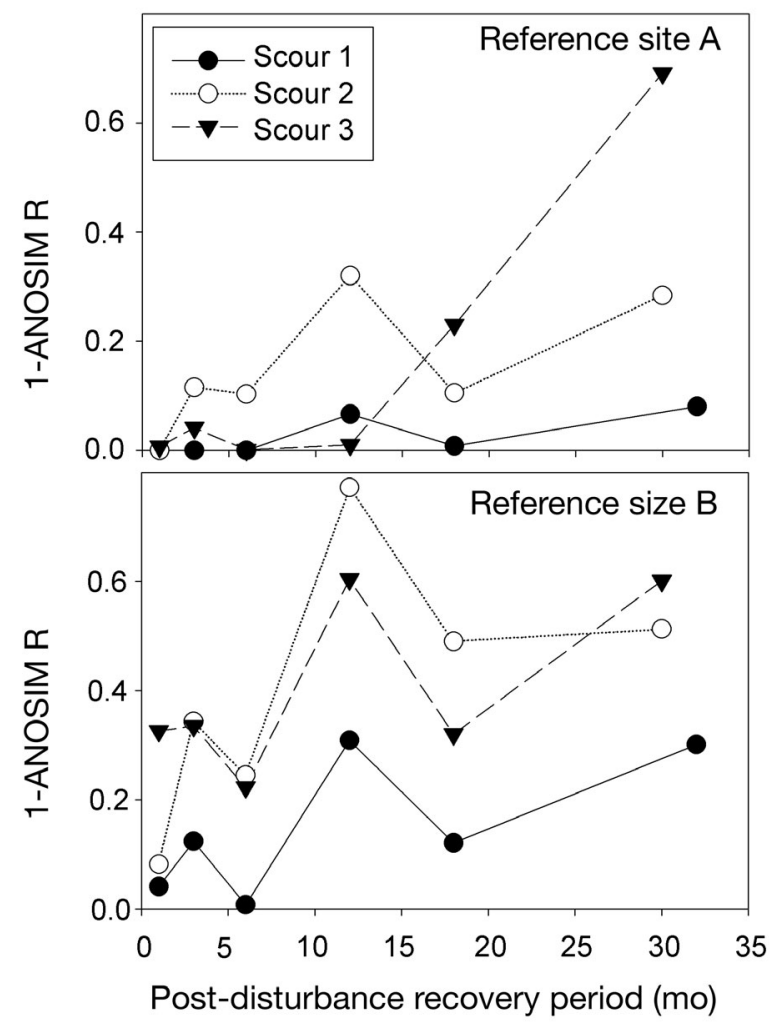

Fig. 5. 1-ANOSIM R values against post-disturbance recovery time for each scour sampled at Adelaide Island, Antarctica. Values are similarity tests between each sample time group and all samples from the References A (top) and B (bottom). All results are significant at the 5\% confidence level and were obtained from 999 permutations 
Table 4. Mean abundances $( \pm \mathrm{SE}$ ) of species with greater abundances in scour samples compared with reference samples (all replicates pooled)

\begin{tabular}{|lrc|}
\hline & \multicolumn{1}{c|}{$\begin{array}{c}\text { Scour } \\
\text { (ind. } 0.03 \mathrm{~m}^{-2} \text { ) }\end{array}$} & $\begin{array}{c}\text { Reference } \\
\text { (ind. } 0.03 \mathrm{~m}^{-2} \text { ) }\end{array}$ \\
\hline Sterechinus neumayeri (echinoid) & $10.0 \pm 3.0$ & $2.0 \pm 0.3$ \\
Ophyrotrocha sp. (polychaete) & $9.0 \pm 1.6$ & $4.0 \pm 1.2$ \\
Austrosignum glaciale (isopod) & $0.8 \pm 0.2$ & $0.2 \pm 0.1$ \\
Nototanais dimorphus (tanaid) & $4.5 \pm 0.8$ & $1.2 \pm 0.3$ \\
Eatoniella calignosa (gastropod) & $3.0 \pm 0.7$ & $0.7 \pm 0.2$ \\
\hline
\end{tabular}

Table 5. Taxa responsible for differences between scoured and reference samples based on similarity percentage (SIMPER) analysis of square-root transformed data. Scour samples taken from each scour at the beginning of the study $(<1$ mo after scour formation, $t 1$ ) and at the end of the study (30-32 mo after scour formation, t30) are compared with samples from Reference A. The 5 taxa that contribute most to the observed differences are shown. Total dissimilarity between groups is shown in parentheses

\begin{tabular}{|c|c|c|c|}
\hline Group & Taxa & $\%$ & Cum\% \\
\hline $\begin{array}{l}\text { Scour } 1 t 1 \\
\text { vs. Ref }(94 \%)\end{array}$ & $\begin{array}{l}\text { Mysella charcoti } \\
\text { Nematodes } \\
\text { Aphelochaeta sp. } \\
\text { Apistobranchus gudrunae } \\
\text { Yoldia eightsi }\end{array}$ & $\begin{array}{r}23 \\
11 \\
7 \\
6 \\
5\end{array}$ & $\begin{array}{l}23 \\
34 \\
41 \\
47 \\
52\end{array}$ \\
\hline $\begin{array}{l}\text { Scour } 1 \text { t32 } \\
\text { vs. Ref }(50 \%)\end{array}$ & $\begin{array}{l}\text { Mysella charcoti } \\
\text { Nematodes } \\
\text { Apistobranchus gudrunae } \\
\text { Ophelina breviata } \\
\text { Aphelochaeta sp. }\end{array}$ & $\begin{array}{r}21 \\
11 \\
6 \\
6 \\
6\end{array}$ & $\begin{array}{l}21 \\
32 \\
38 \\
44 \\
50\end{array}$ \\
\hline $\begin{array}{l}\text { Scour } 2 t 1 \\
\text { vs. Ref }(89 \%)\end{array}$ & $\begin{array}{l}\text { Mysella charcoti } \\
\text { Nematodes } \\
\text { Aphelochaeta sp. } \\
\text { Apistobranchus gudrunae } \\
\text { Yoldia eightsi }\end{array}$ & $\begin{array}{r}23 \\
13 \\
7 \\
7 \\
5\end{array}$ & $\begin{array}{l}23 \\
36 \\
43 \\
50 \\
55\end{array}$ \\
\hline $\begin{array}{l}\text { Scour } 2 t 30 \\
\text { vs. Ref }(37 \%)\end{array}$ & $\begin{array}{l}\text { Mysella charcoti } \\
\text { Nematodes } \\
\text { Aphelochaeta sp. } \\
\text { Apistobranchus gudrunae } \\
\text { Yoldia eightsi }\end{array}$ & $\begin{array}{r}16 \\
12 \\
8 \\
6 \\
4\end{array}$ & $\begin{array}{l}16 \\
28 \\
36 \\
42 \\
46\end{array}$ \\
\hline $\begin{array}{l}\text { Scour } 3 t 1 \\
\text { vs. Ref }(74 \%)\end{array}$ & $\begin{array}{l}\text { Mysella charcoti } \\
\text { Nematodes } \\
\text { Apistobranchus gudrunae } \\
\text { Aphelochaeta sp. } \\
\text { Scleroconcha sp. }\end{array}$ & $\begin{array}{r}21 \\
13 \\
8 \\
7 \\
5\end{array}$ & $\begin{array}{l}21 \\
34 \\
42 \\
49 \\
54\end{array}$ \\
\hline $\begin{array}{l}\text { Scour } 3 t 30 \\
\text { vs. Ref }(32 \%)\end{array}$ & $\begin{array}{l}\text { Mysella charcoti } \\
\text { Nematodes } \\
\text { Ophelina breviata } \\
\text { Aphelochaeta sp. } \\
\text { Apistobranchus gudrunae }\end{array}$ & $\begin{array}{r}10 \\
10 \\
10 \\
10 \\
7\end{array}$ & $\begin{array}{l}10 \\
20 \\
30 \\
40 \\
47\end{array}$ \\
\hline
\end{tabular}

the nematode group were consistently the highest contributors to the dissimilarity between the 2 sample groups (Table 5). These taxa were highly abundant in undisturbed sediments and did not recover in any of the scours to similar abundances during the study period.

\section{DISCUSSION}

Following each iceberg grounding, faunal abundance and species richness were markedly lower in the newly formed scours compared with undisturbed sediments. We observed a mean reduction in total abundance of $\sim 95 \%$ at Hangar Cove, almost as great as the $99.5 \%$ reduction recorded by Peck et al. (1999) at a shallow water site at Signy Island. High benthic mortality caused by iceberg impacts in Antarctica has also been observed at Anvers Island (Richardson \& Hedgepeth 1977) and King George Island (Bromberg et al. 2000), whilst collisions between ice and seabed are equally as destructive in Arctic waters (Conlan et al. 1998). Smale et al. (2007) give a detailed account of the immediate effects of multiple iceberg groundings on the benthic communities at 3 contrasting sites at Adelaide Island, reporting an average reduction in macrofaunal abundance of $95 \%$ from 12 iceberg impacts.

At Hangar Cove, many taxa returned to the scoured areas rapidly. Species richness and community structure in the scours was comparable to that in the reference zones after 12 mo. Also, after the 30 mo observation period, we recorded no differences in the abundances of all crustacean groups (some of which had recovered within $20 \mathrm{~d}$ ), gastropods and polychaetes between scours and reference zones. At Signy Island, South Orkneys, Peck et al. (1999) also reported the rapid return of some taxa into scours. Influxes of scavengers and detritivores into newly formed scours have been previously observed (Richardson \& Hedgepeth 1977) and a high abundance of motile scavengers, particularly crustaceans, were able to move rapidly into disturbed areas following iceberg retreat at Hangar Cove. Furthermore, the study site is exposed to the prevailing northerly wind at Rothera Point and, as such, is subjected to moderate wave disturbance and intense ice disturbance (Brown et al. 2004, Smale et al. 2007). It is likely that small infauna, such as bivalves and gastropods, were advected into scours by water movements induced by grounding icebergs and wave action.

A number of species found in scours are known to be effective pioneers, and are well adapted to recolonise disturbed sediments. For example, the small burrowing polychaetes Kefersteinia fauveli and Ophryotrocha sp., both of which are motile and recruit rapidly, were more abundant in scours than in undisturbed sediments. These polychaetes also have elevated abundances in sediments disturbed by anchor ice at McMurdo Sound (Lenihan \& Oliver 1995, Conlan et al. 2004). The other species that quickly returned to the scours were either highly mobile or small enough to be advected by water movements. There is also some recent evidence to sug- 
gest that iceberg groundings select for small fauna, which may fall into scour depressions as grounded icebergs retreat (Smale et al. 2007). Conclusions about the nematode group must be drawn very tentatively, as the majority of individuals probably passed through the $0.5 \mathrm{~mm}$ mesh size used in this study. Thus, the data presented here are likely to be skewed toward large individuals. Nonetheless, the data suggested that the large size fraction of this taxa recovered, to some degree, toward reference levels of abundance (as would be expected, see Lee et al. 2001).

Conlan \& Kvitek (2005) sampled 19 iceberg scours of different ages in the Canadian High Arctic. Scour assemblages reached 1-ANOSIM R values of 0.6 eight yr after the disturbance event, whereas that value was recorded after just $1 \mathrm{yr}$ in the current study. The Arctic assemblages were richer than those at Hangar Cove (a total of 129 taxa compared with 66 in the current study) and the study sites were mostly in deeper water (and therefore almost certainly less disturbed by ice). The simple infaunal assemblages at the highly disturbed Hangar Cove study site are seemingly well adapted to rapid recovery following disturbance events. Also, the site is intensely disturbed and it is likely that even the reference zones, which were either in deeper water or partially protected, are impacted frequently enough to prevent the persistence of late successional stages.

Conversely, observations from the Weddell Sea shelf have suggested that scour communities remain distinct from adjacent undisturbed communities for decades (Gutt et al. 1996, Gutt \& Starmans 2001). This is primarily due to rich, slow growing sponge assemblages dominating the undisturbed substratum, which is not the case at the shallow-water Hangar Cove study site. Whilst many processes are thought to be slower in the Antarctic than elsewhere, it seems that some shallowwater habitats are highly dynamic and benthic recovery may be surprisingly rapid. This could be of particular importance in the rapidly warming West Antarctic Peninsula region, where decreasing sea ice duration (Vaughan et al. 2003), glacier acceleration (Pritchard \& Vaughan 2007) and ice shelf retreat (Scambos et al. 2000) are likely to increase the frequency of iceberg disturbance in shallow waters.

Finally, we observed considerable small-scale variation (i.e. tens of metres) in community structure at Hangar Cove. The 2 reference zones, just $30 \mathrm{~m}$ apart, supported dissimilar assemblages, whilst each scour assemblage was also distinct. A number of factors may have induced variability in assemblage composition between scours, including the intensity of the iceberg grounding, community structure directly outside the scour, scour morphology and localised currents. Smallscale spatial variability is often the norm for shallowwater soft sediment systems, and Antarctic habitats are no exception (Stark 2000, Stark et al. 2003, Conlan et al. 2004). Whilst this variability complicates predictions of recovery rates and patterns, it is perhaps fundamental in promoting and maintaining benthic diversity, which is particularly high at the regional scale on the continental shelf of Antarctica (Gray 2001, Clarke \& Johnston 2003, Gutt \& Piepenburg 2003).

Acknowledgements. The authors would like to thank the wintering teams of 2004 and 2005 at Rothera Research Station for impeccable assistance in the field. The UK NFSD is acknowledged for supporting diving operations at Rothera Research Station. K. Linse, C. De Broyer, S. Hull, S. Kaiser and B. Hilbig are thanked for their taxonomic expertise. This work was part of a larger ecological study that aimed to assess the influence of ice disturbance on biodiversity at Adelaide Island. The study was funded by the BIOREACH and BIOPEARL projects of the British Antarctic Survey's core science programme.

\section{LITERATURE CITED}

Arntz WE, Brey T, Gallardo VA (1994) Antarctic zoobenthos. Oceanogr Mar Biol Annu Rev 32:251-303

Barnes DKA (1995) Sublittoral epifaunal communities at Signy Island, Antarctica. II. Below the ice-foot zone. Mar Biol 121:565-572

Barnes DKA (2002) Polarisation of competition increases with latitude. Proc R Soc Lond B Biol Sci 269:2061-2069

Barnes DKA, Brockington S (2003) Zoobenthic biodiversity, biomass and abundance at Adelaide Island, Antarctica. Mar Ecol Prog Ser 249:145-155

Bromberg S, Nonato EF, Corbisier TN, Petti MAV (2000) Polychaete distribution in the near-shore zone of Martel Inlet, Admirality Bay (King George Island, Antarctica). Bull Mar Sci 67:175-188

Brown KM, Fraser KPP, Barnes DKA, Peck LS (2004) Links between the structure of an Antarctic shallow-water community and ice-scour frequency. Oecologia 141:121-129

Clarke A, Johnston NM (2003) Antarctic marine benthic diversity. Oceanogr Mar Biol Annu Rev 41:47-114

Clarke KR (1993) Non-parametric multivariate analysis of changes in community structure. Austral Ecol 18:117-143

Clarke KR, Warwick RM (2001) Change in marine communities: an approach to statistical analysis and interpretation, 2nd edn. PRIMER-E, Plymouth

Conlan KE, Kvitek RG (2005) Recolonization of soft-sediment ice scours on an exposed Arctic coast. Mar Ecol Prog Ser 286:21-42

Conlan KE, Lenihan HS, Kvitek RG, Oliver JS (1998) Ice scour disturbance to benthic communities in the Canadian High Arctic. Mar Ecol Prog Ser 166:1-16

> Conlan KE, Kim SL, Lenihan HS, Oliver JS (2004) Benthic changes during 10 years of organic enrichment by McMurdo Station, Antarctica. Mar Pollut Bull 49:43-60

Connell JH (1978) Diversity in tropical rainforests and coral reefs. Science 199:1302-1310

Dayton PK, Robbiliard GA, Paine RT, Dayton LB (1974) Biological accomodation in the benthic community at McMurdo Sound, Antarctica. Ecol Monogr 44:105-128

de la Mare WK (1997) Abrupt mid-twentieth-century decline in Antarctic sea-ice extent from whaling records. Nature 389:57-60

Dollar SJ, Tribble GW (1993) Recurrent storm disturbance and recovery: a long-term study of coral communities in Hawaii. Coral Reefs 12:223-233 
Gray JS (2001) Antarctic marine benthic biodiversity in a world-wide latitudinal context. Polar Biol 24:633-641

Gutt J, Piepenburg D (2003) Scale-dependent impact on diversity of Antarctic benthos caused by grounding of icebergs. Mar Ecol Prog Ser 253:77-83

Gutt J, Starmans A (2001) Quantification of iceberg impact and benthic recolonisation patterns in the Weddell Sea (Antarctica). Polar Biol 24:615-619

Gutt J, Starmans A, Dieckmann G (1996) Impact of iceberg scouring on polar benthic habitats. Mar Ecol Prog Ser 137: $311-316$

Hughes KA (2004) Reducing sewage pollution in the Antarctic marine environment using a sewage treatment plant. Mar Pollut Bull 49:850-853

Jackson JBC, Kirby MX, Berger WH, Bjorndal KA and others (2001) Historical overfishing and the recent collapse of coastal ecosystems. Science 293:629-637

Jewett SC, Dean TA, Smith RO, Blanchard A (1999) 'Exxon Valdez' oil spill: impacts and recovery in the soft-bottom benthic community in and adjacent to eelgrass beds. Mar Ecol Prog Ser 185:59-83

Kaiser MJ, Spencer BE (1996) The effects of beam-trawl disturbance on infaunal communities in different habitats. J Anim Ecol 65:348-358

Lee HJ, Vanhove S, Peck LS, Vincx M (2001) Recolonisation of meiofauna after catastrophic iceberg scouring in shallow Antarctic sediments. Polar Biol 24:918-925

Lenihan HS, Oliver JS (1995) Anthropogenic and natural disturbances to marine benthic communities in Antarctica. Ecol Appl 5:311-326

Lovell LL, Trego KD (2003) The epibenthic megafaunal and benthic infaunal invertebrates of Port Foster, Deception Island (South Shetland Islands, Antarctica). Deep-Sea Res II 50:1799-1819

McCook LJ, Chapman ARO (1993) Community succession following massive ice-scour on a rocky intertidal shore: recruitment, competition and predation during early, primary succession. Mar Biol 115:565-575

Meredith MP, King JC (2005) Rapid climate change in the ocean west of the Antarctic Peninsula during the second half of the 20th century. Geophys Res Lett 32:L19604

Oliver JS, Slattery PN (1985) Destruction and opportunity on the sea-floor - effects of gray whale feeding. Ecology 66: 1965-1975

Orheim O (1987) Icebergs in the Southern Ocean (abstract). Ann Glaciol 9:241-242

Pearson RG (1981) Recovery and recolonization of coral reefs. Mar Ecol Prog Ser 4:105-122

Peck LS, Brockington S, Vanhove S, Beghyn M (1999) Community recovery following catastrophic iceberg impacts in

Editorial responsibility: Otto Kinne,

Oldendorf/Luhe, Germany a soft-sediment shallow-water site at Signy Island, Antarctica. Mar Ecol Prog Ser 186:1-8

Pritchard H, Vaughan DG (2007) Widespread acceleration of tidewater glaciers on the Antarctic Peninsula. J Geophys Res 112: F03S20 doi 10.1029/2006JF000597

Pugh PJA, Davenport J (1997) Colonisation vs. disturbance: the effects of sustained ice-scouring on intertidal communities. J Exp Mar Biol Ecol 210:1-21

Richardson ME, Hedgepeth JW (1977) Antarctic soft-bottom, macrobenthic community adaptations to a cold, stable, highly productive, glacially affected environment. In: Llano GA (ed) Adaptations within Antarctic ecosystems. Smithsonian Institution Press, Washington, DC, p 181-196

Scambos T, Huble C, Fahnestock MA, Bohlander J (2000) The link between climate warming and the break-up of ice shelves in the Antarctic Peninsula. J Glaciol 46:516-530

Smale DA (2007) Ice disturbance intensity structures benthic communities in nearshore Antarctic waters. Mar Ecol Prog Ser 349:89-102

Smale DA, Barnes DKA, Fraser KPP (2007) The influence of depth, site exposure and season on the intensity of iceberg scouring in nearshore Antarctic waters. Polar Biol 30: 769-779

Smale DA, Barnes DKA, Fraser KPP (2007) The influence of ice scour on benthic communities at 3 contrasting sites at Adelaide Island, Antarctica. Austral Ecol 32:878-888

Smith SDA, Simpson RD (1998) Recovery of benthic communities at Macquarie Island (sub-Antarctic) following a small oil spill. Mar Biol 131:567-581

Smith RC, Stammerjohn S (2001) Variations of surface air temperature and sea ice extent in the West Antarctic Peninsula (WAP) region. Ann Glaciol 33:493-500

Stark JS (2000) The distribution and abundance of soft-sediment macrobenthos around Casey Station, East Antarctica. Polar Biol 23:840-850

Stark JS, Riddle MJ, Simpson RD (2003) Human impacts in soft-sediment assemblages at Casey Station, East Antarctica: spatial variation, taxonomic resolution and data transformation. Austral Ecol 28:287-304

Thrush SF, Dayton PK (2002) Disturbance to marine benthic habitats by trawling and dredging: implications for Marine Biodiversity. Annu Rev Ecol Syst 33:449-473

Turner J, Colwell SR, Marshall GJ, Lachlan-Cope TA and others (2005) Antarctic climate change during the last 50 years. Int J Climatol 25:279-294

Vaughan DG, Marshall GJ, Connolley WM, Parkinson C and others (2003) Recent rapid regional climate warming on the Antarctic Peninsula. Clim Change 60:243-274

Submitted: August 14, 2007; Accepted: October 29, 2007

Proofs received from author(s): January 30, 2008 